\title{
ASSESSMENT ON THE REUSE AND RECYCLING OF DOMESTIC SOLID WASTE IN MALAYSIA
}

\author{
Siti Akhtar MAHAYUDDIN ${ }^{1}$, Noor Rizallinda ISHAK ${ }^{2}$, Wan Akmal Zahri WAN \\ ZAHARUDDIN ${ }^{3}$, Jannatun Naemah ISMAM${ }^{4}$
}

DOI: 10.21163/GT_2020.151.24

\begin{abstract}
:
The most preferred waste management practices are to prevent or minimize waste. Public participation in domestic waste separation for reuse and recycling is the key to reduce waste disposal or increase the amount of waste diverted from landfill. These practices are influenced by knowledge of the public on the concept of source separation, reuse, and recycle, varieties of recyclable goods and methods of disposal for domestic waste. This paper proposes an assessment to explore the reuse and recycling of domestic solid waste by local residents in Malaysia. The propose assessment will include field experiment at selected housing schemes in Malaysia. The experiment will become a platform to guide and educate the public to manage domestic waste. These hands-on practices will be closely monitored. Three interventions will be conducted to identify their current practices of domestic waste management. The interventions will be "information only", "information and norms" and "information and monetary incentives". The record of domestic waste collected by the local authorities, before and after these interventions will be checked and analysed. The findings of the experiment shall indicate the influencing factors for separation at source for domestic waste.
\end{abstract}

Key-words: Domestic Waste, Waste Management, Reduce, Reuse, Recycle

\section{INTRODUCTION}

Greening the domestic solid waste management require " $3 \mathrm{R}$ - Reduce, Reuse and Recycle" activities to minimize or prevent waste generation. The green solid waste management is indicated by the least practice of waste disposal (with reference to the waste management hierarchy). The participation of residents in domestic solid waste separation, reuse and recycling is the key to reduce waste disposal or increase the amount of waste diverted from landfill. These activities influenced by knowledge of the residents towards recycling concept. This concept covers the varieties in good recycling and disposal method of solid waste. Examination of the current trend and pattern of waste generation and identification of the green practices by the residents is vital in greening Malaysia. The estimation of the generation of solid waste in Malaysia shows an increase pattern for the year of 2012 to 2017 (Fig.1) (MAMPU 2018). This estimation was based on the generation rate of $1.17 \mathrm{~kg}$ per capita per day. The population growth in Malaysia will directly increase the generation of solid waste. However, the actual collection of domestic solid waste by the local authority shows an up and down pattern (Fig. 2). The influencing factors and decisionmaking mechanism of the residents need to be strongly understood. This paper proposes an assessment on the reuse and recycling of domestic solid waste practiced in Malaysia. This assessment will focus on the identification of the generic stream of domestic waste recycling

\footnotetext{
${ }^{1234}$ Faculty of Architecture, Planning and Surveying, Universiti Teknologi MARA, Seri Iskandar Campus,Perak,MALAYSIA, sitia880@uitm.edu.my,noorr399@uitm.edu.my, wan450@uitm.edu.my, janna001@uitm.edu.my;
} 
in Malaysia, identification of the green practices in reuse and recycling of solid waste adopted at household level and the determination of the influencing factor of green practices in reuse and recycling of domestic solid waste.

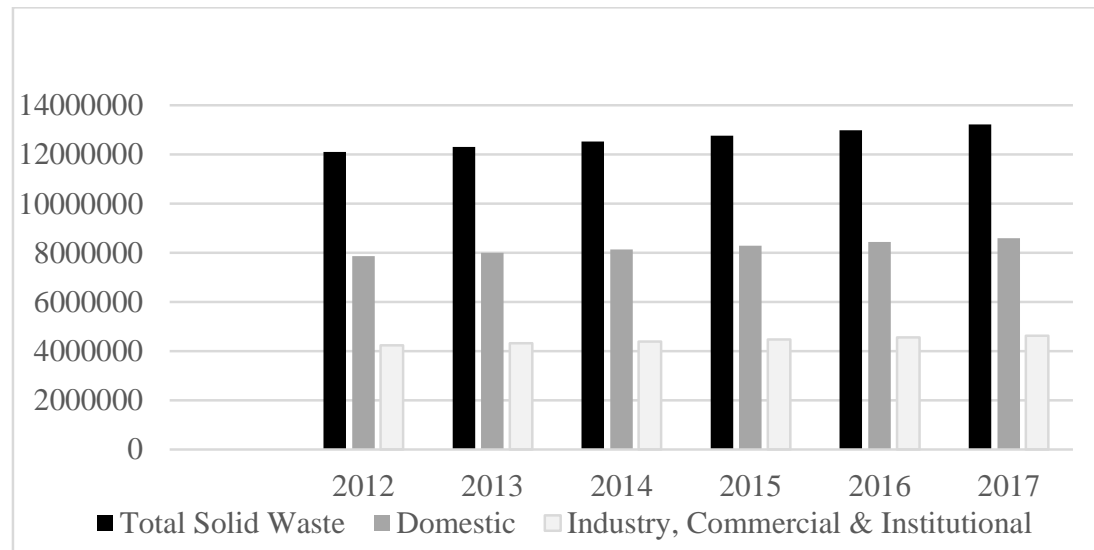

Fig. 1. Estimation of Solid Waste Generation in Malaysia (2012-2017)

Source: MAMPU (2018)

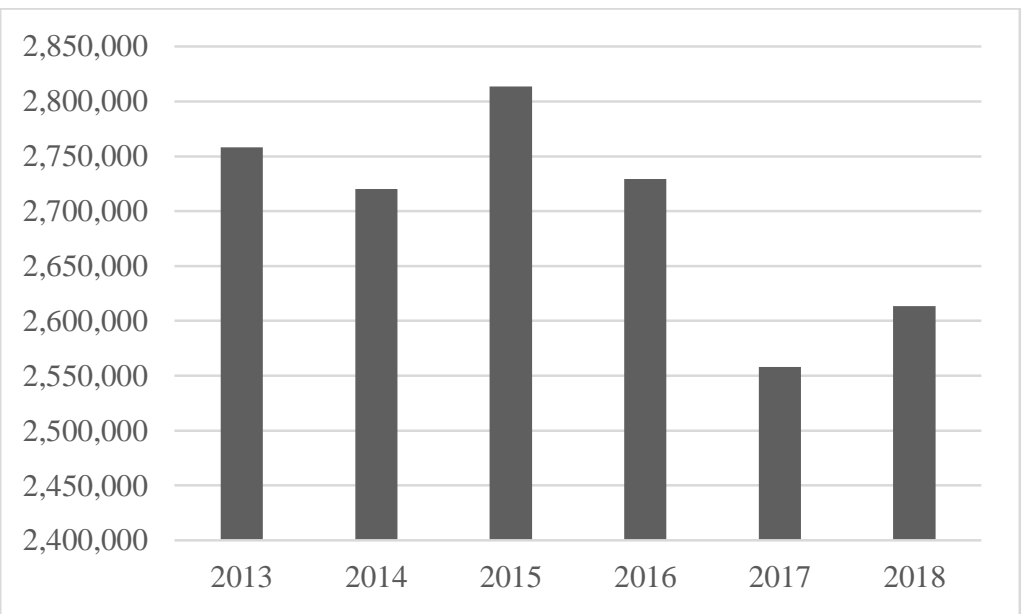

Fig. 2. Collection of Domestic Solid Waste (2013 - 2018)

Source: MAMPU (2019a)

\section{REVIEW ON DOMESTIC SOLID WASTE MANAGEMENT}

The solid waste management becomes a major concern among the policy makers and planners. The highest generator of solid waste in Malaysia is domestic waste as shown in Fig. 1 above (MAMPU 2018; Ministry of Housing and Local Government, 2006). The adoption of an effective waste minimisation strategy by the government is expected to promote sustainable solid waste management. Greening the domestic solid waste management is a way to minimize and prevent waste generation through regular practice of 
Reduce, Reuse and Recycle. A green solid waste management is indicated by the least practice of waste disposal (with reference to the waste management hierarchy). The participation of residents in domestic solid waste separation, reuse and recycling is the key to reduce waste disposal or increase the amount of waste diverted from landfill. The composition of recyclable solid waste sorting at source by residents in Kuala Lumpur, Putrajaya, Pahang, Perlis, Kedah, Negeri Sembilan, Melaka and Johor had been recorded as in Fig. 3 (MAMPU 2019b). The participation of the residents in this activity could be improved and increased.

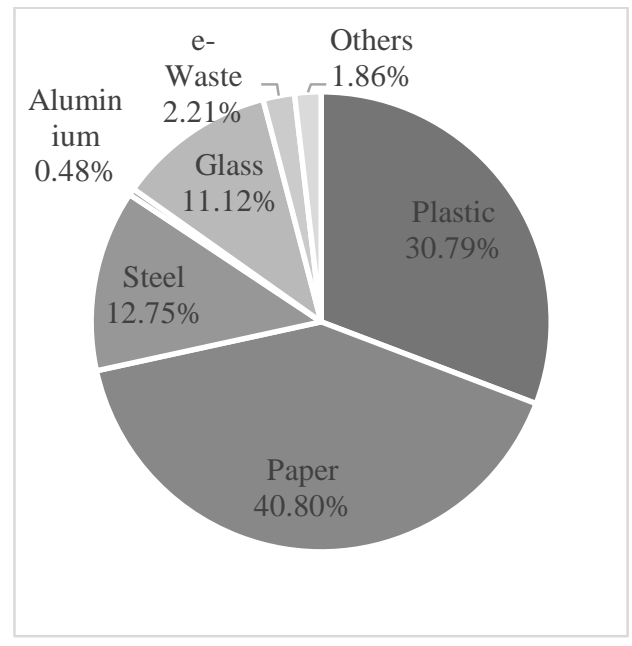

Fig. 3. Composition of recyclable solid waste sorting at source Source: MAMPU (2019b).

In product recovery, the lowest hierarchy is recycling (Amelia, et al. 2009). Recycle is a simple method to reduce disposal problem. Recycling activities could expand the lifespan of the existing landfill. Therefore, seeking new landfill site could be delayed or avoided. The Suitability Index for Waste Landfills considers public health, minimal impact on the environment, and provide safe disposal of waste (Manoiu et al. 2013). In addition, the recycling program is more economical by substituting raw materials with used materials, conserves energy, and creates jobs. (Meen-Chee and Narayanan, 2006). The community must be knowledgeable on recycling techniques, methods and benefits. The process of recycling also must be appropriate, low-cost, and easy (Purcell and Magette. 2010). The daily percentage of recyclable materials disposed of at landfill is about 65\% (Meen-Chee and Narayanan, 2006). In Malaysia, only few recycling industries are available despite the positive sign of recycling activities (Fig.3). The recycling industry need to be increased and enhanced (Saeed et al., 2009). Community Based Solid Waste Management (CBM) training course is one example of sharing and dissemination of knowledge to all parties (Tantanee and Hantrakul, 2016).

Examination of the current waste generation patterns and identification of the green practices of reuse and recycling by residents is vital in greening the country. Despite of that, a clear understanding of the main influencing factors and decision-making mechanism of the 
residents are also required. Therefore, all parties should collaborate to improve the good practices and comprehensive solid waste management. The success of the implementation of solid waste management depends on the collective effort from all parties involved. This achievement is indicated by the inclusiveness, fully integration with the economic and social practices, and incorporation with all parties.

\section{ASSESSMENT ON THE REUSE AND RECYCLING OF DOMESTIC SOLID WASTE}

The proposed assessment in reuse and recycling of domestic solid waste in Malaysia comprise of three stages namely identification of the study area and sampling strategy, fieldwork setting and experiment design and intervention (Fig. 4).

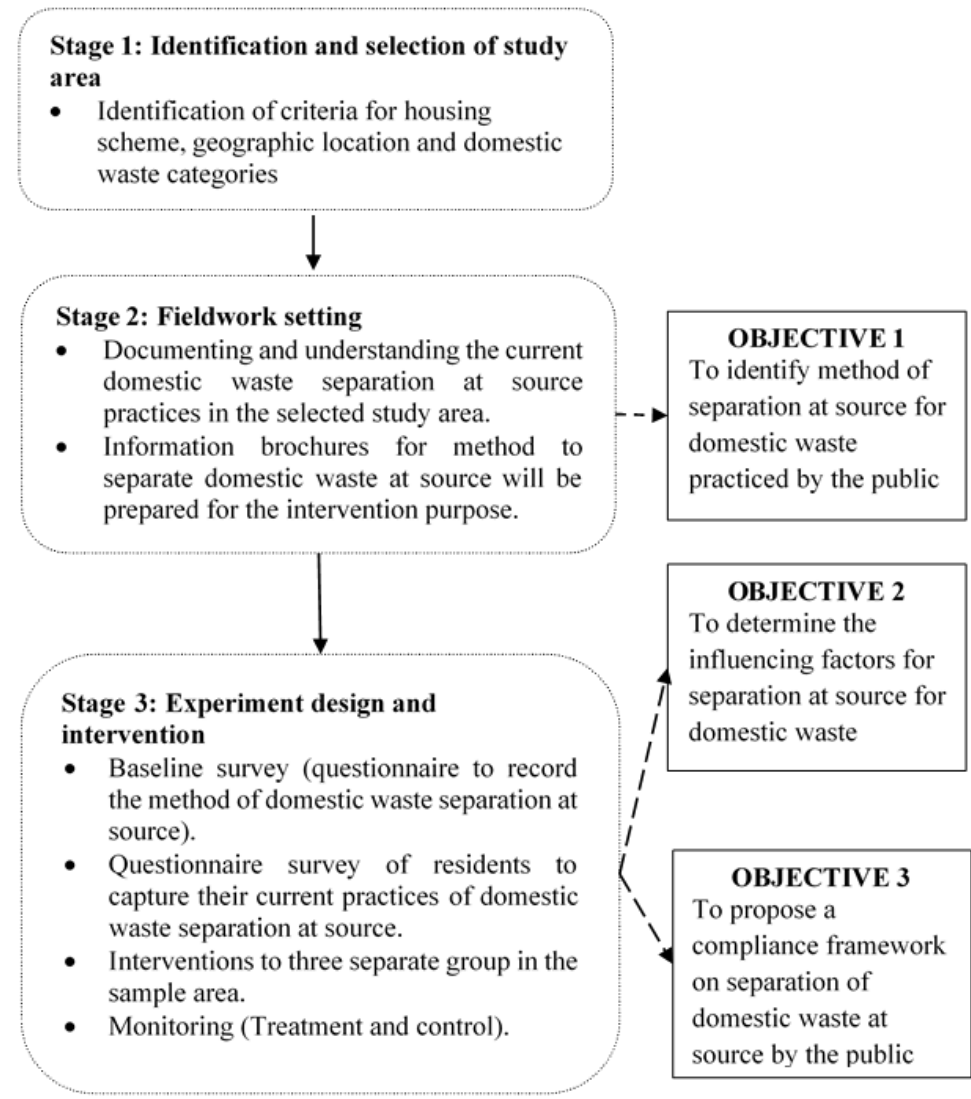

Fig. 4. Assessment Flow Chart.

\subsection{Identification and selection of study area}

The study area will be selected based on the population density and recorded data of household waste collected by the municipality or district in Malaysia. The sample will be drawn from the housing scheme area with a cluster randomization technique. The investigation on greening the domestic solid waste management will focus on the reuse and 
recycling activities by residents in selected municipalities with high density of population in Malaysia.

Review on available data from reliable sources provides a baseline for the identification and selection of study area. The estimation of solid waste generation in for every state in Malaysia for the year 2020, 2025 and 2030 shows an increasing pattern (Fig. 5). The highest generation of solid waste will be in Selangor.

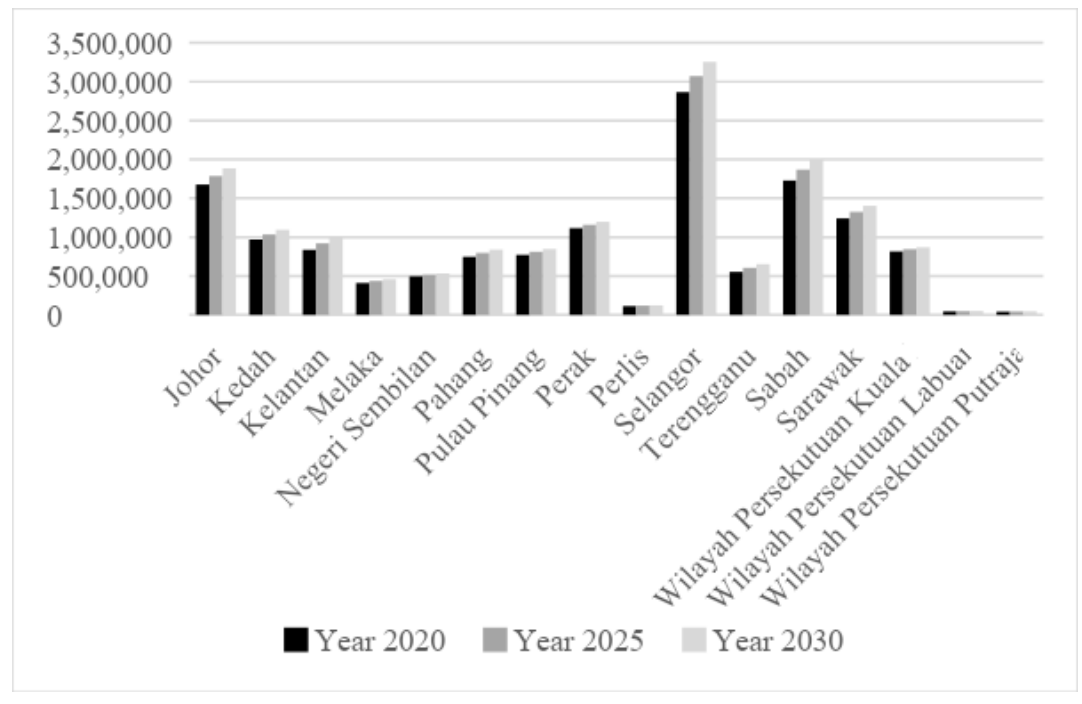

Fig. 5. Estimation of Solid Waste Generation by State in Malaysia (2020, 2025 \& 2030) Source: MAMPU (2019c).

The geographical areas of study will be pre-determined in accordance to zoning/under the management of Solid Waste Corporation Malaysia (SWCorp) as in Fig.6. In Peninsular Malaysia, only 7 areas are managed by this Corporation. This investigation will include recycling concept, recyclable materials and disposal method of domestic solid waste. 


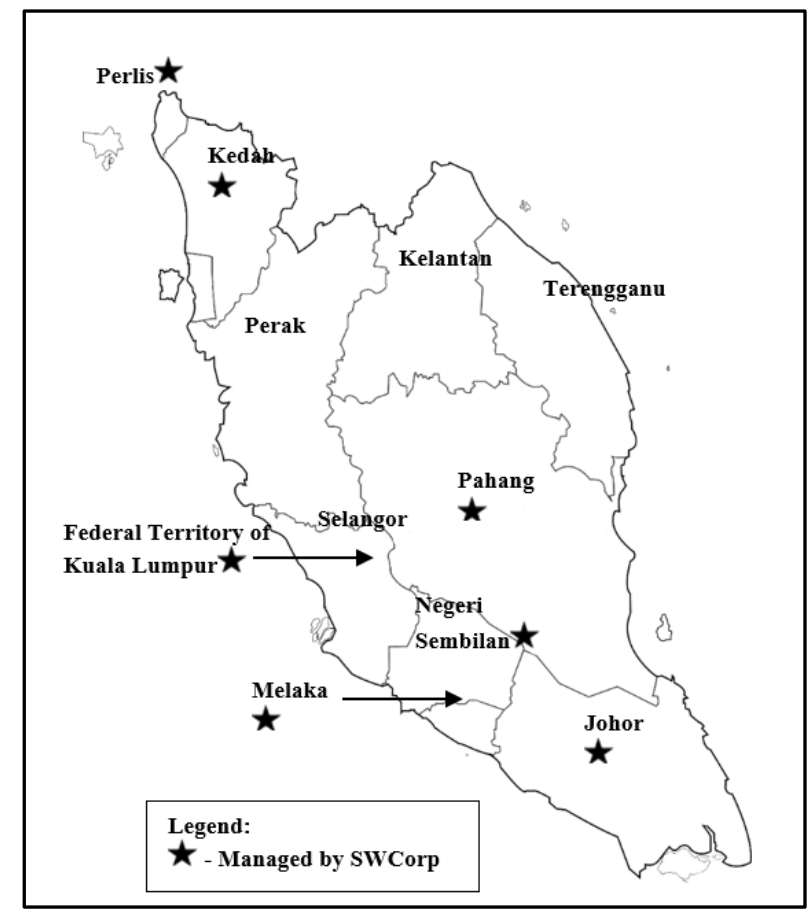

Fig. 6. Area under the Management of Solid Waste Corporation Source: SWCorp (2020).

The investigation on greening the household solid waste management will focus on the reuse and recycling activities by residents in selected municipalities with high density of population in Malaysia. There are seven categories of recyclable waste in Malaysia namely plastic, paper, aluminium, glass, steel, battery (lead) and others. Plastic found to be the largest composition of recycled waste for the year 2014 to 2018 (Fig 7) (MAMPU 2019d). Second largest composition of recycled waste was paper and the least was battery (lead). Further investigation will be conducted as in the proposed methodology to promote recycling activities for domestic waste. This investigation will include concept of recycling, recyclable goods and methods of disposal for household solid waste. 


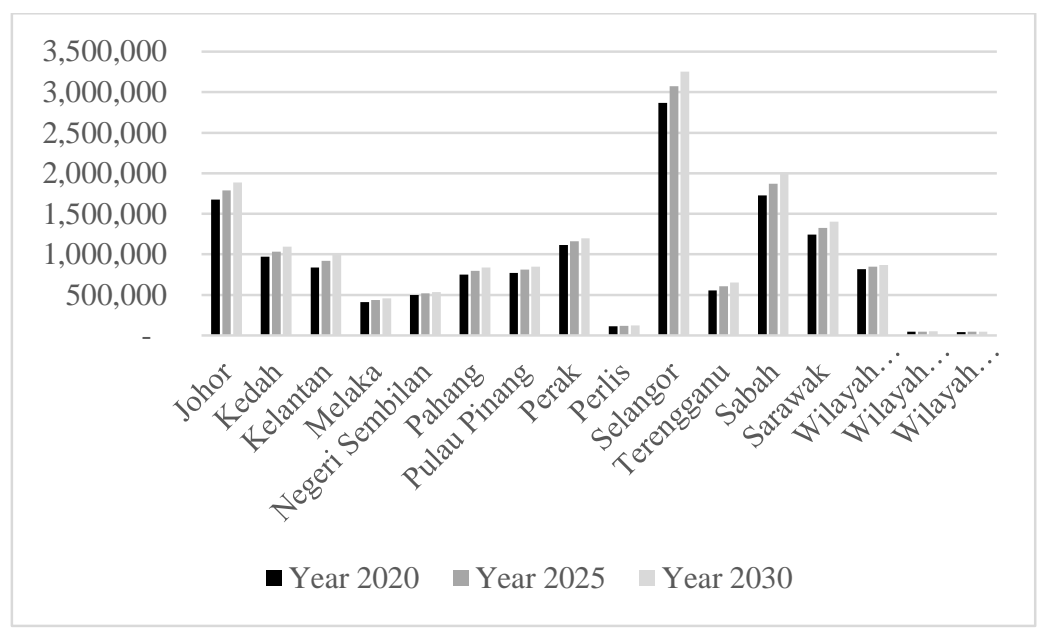

Fig. 7. Recycled Solid Waste Composition (Source: MAMPU, 2019d).

\subsection{Fieldwork setting}

The fieldwork setting will be divided into two categories. First is documenting and understanding the generic waste collection chain in the selected study area. The documentation will cover the recorded data of household waste for disposal and recyclable waste collected. Second is preparing the information brochures for green practices of domestic waste management for the intervention purpose. The information brochures will include waste management hierarchy and best practices of waste management. Therefore, this brochure becomes an additional guide to the public on how to sort domestic waste.

\subsection{Experiment design and intervention}

The experiment becomes a platform to guide and educate the residents on the green practices of managing household waste. This "hands-on" practices will be closely monitored by the research team. The experiment involves baseline survey, interventions and monitoring.

a. Baseline survey (questionnaire to record the domestic waste disposal practices).

Questionnaire survey on domestic waste management by the residents is to capture their current practices of reuse and recycling. The survey will inquire the waste generation frequency, waste disposal frequency, waste disposal method, types of domestic waste generated, and reuse or recycle methods applied at their home. The domestic waste generated will be weighed before "Interventions".

b. Interventions - There are three category of interventions will be conducted namely Information only; Information and norms; Information and monetary incentive. These interventions will be conducted to identify the current practices of households in managing their household waste. Different sample of housing scheme will be randomly chosen to receive any one of these interventions. The second weighing of household waste will be conducted to compare the effectiveness of the Interventions. 
c. Monitoring (Treatment and control).

The monitoring will be conducted twice to evaluate the changes of behavioural of the household in managing waste. During the monitoring, the household waste will be weighed.

\section{CONCLUSIONS}

The expected findings from the proposed assesment will benefit the residents and local authorities. The residents will have a greener environment due to less pollution caused by household waste. Subsequently, the generation of employment and income due to recycling of household solid waste expected to rise. This initiative could positively enhance the economic distribution. The main potential benefit to local authorities will be easier to manage household solid waste when the reuse and recycling activities are increase. Cost saving for the collection and transportation of household waste disposed at landfill. The approach from this propose assessment can be directly shared with the potential beneficiaries through meetings, discussions, demonstration and any other dissemination of knowledge activities. The potential beneficiaries should be able to sustain the green practices in managing household solid waste after series of knowledge sharing. The identified green practices in reuse and recycling of domestic waste could indicate sustainable living in Malaysia. These good practices would minimize domestic waste generation. Thus, the Sustainable Development Goal could be achieved.

The examination of the existing waste generation patterns, and identification of the green practices applied at the domestic level is vital in greening the country. A strong understanding on the main influencing factors and decision-making mechanism of the residents is essential.

\section{REFERENCES}

Amelia, L., Wahab, D. A., Haron, C. C., Muhamad, N., \& Azhari, C. H. (2009) Initiating Automotive Component Reuse in Malaysia. Journal of Cleaner Production. 17, 1572-1579.

Meen-Chee, H., Narayanan, S. (2006) Restoring the Shine to a Pearl: Recycling Behaviour in Penang, Malaysia. Development and Change. 37, 1117-1136.

Ministry of Housing and Local Government, Malaysia, Waste Generation Statistics, (http://www.kpkt.gov., 2006). (accessed date: 20 November 2019)

Purcell, M., Magette, W.L. (2010) Attitudes and Behaviour Towards Waste Management in the Dublin, Ireland region. WasteManagement. 30, 1997-2006.

Saeed, M. O., Hassan M.N., Mujeebu M.A. (2009) Assessment of Municipal Solid Waste Generation and Recyclable Materials Potential in Kuala Lumpur, Malaysia. Waste Management. 29, 22092213.

Malaysian Administrative Modernisation and Management Planning Unit (MAMPU). (2018) Estimation of Solid Waste Generation in Malaysia for 2012-2017. http://www.data.gov.my/data/ms_MY/dataset/anggaran-penjanaan-sisa-pepejal-di-malaysia-padatahun-2012-2017/resource/ce713428-2a65-422a-b2b4-cd43f9c15995 (accessed date: 20 December 2019)

Malaysian Administrative Modernisation and Management Planning Unit (MAMPU) (2019a) Solid Waste Disposal Collection for Domestic and Public Cleansing. http://www.data.gov.my/data/ms_MY/dataset/berat-kutipan-sisa-pepejal-dilupus-bagi-sisadomestik-sisa-pukal-dan-sisa-pembersihan-awam/resource/7f14df7d-f701-4be0-8c0892e8bee985bf (accessed date: 20 December 2019). 
Malaysian Administrative Modernisation and Management Planning Unit (MAMPU) (2019b) Annual Collection of Recyclable Solid Waste Sorted at Source.

http://www.data.gov.my/data/ms_MY/dataset/sisa-kitar-semula-kategori-melalui-programpengasingan-sisa-pepejal-di-punca/resource/fc84a89e-a535-48f4-83c9-63888beecc66 (accessed date: 20 December 2019)

Malaysian Administrative Modernisation and Management Planning Unit (MAMPU) (2019c) Estimation of Solid Waste Generation by State for 2020, 2025 and 2030. http://www.data.gov.my/data/ms_MY/dataset/anggaran-penjanaan-sisa-pepejal-mengikutnegeri/resource/6cec4062-9b86-4e39-b7b9-76d99fbcd06a (accessed date: 20 December 2019)

Malaysian Administrative Modernisation and Management Planning Unit (MAMPU) (2019d) Composition of Recyclable Solid Waste in 2005 - 2018. http://www.data.gov.my/data/ms_MY/dataset/komposisi-sisa-pepejal-yang-dikitarsemula/resource/6c2087f9-c086-49e1-9b67-ed0c2738248c (accessed date: 20 December 2019)

Manoiu, V, Fontanine, I, Costache, R, Pravalie, R., Mitof, I. (2013) Using GIS Techniques for Assessing Waste Landfill Placement Suitability. Case Study: Prahova County, Romania. Geographia Technica, 8, (2), 47-56.

SWCorp. 2020. Solid Waste Corporation Malaysia. http://www.swcorp.gov.my/ (accessed date: 20 March 2020)

Tantanee, S., Hantrakul, S. (2019) Municipal Waste Management Challenge of Urbanization: Lesson Learned from Phitsanulok, Thailand. Geographia Technica, 14, Special Issue, 39-46. 